\title{
要素 $(\mathrm{N}, \mathrm{P}, \mathrm{K}, \mathrm{Ca})$ 單用が水䅨收量及粐灰成分 \\ $\left(\mathrm{SiO}_{2}, \mathrm{CaO}, \mathrm{P}_{2} \mathrm{O}_{5}\right)$ 空素炭素含有量に及代す影響
}

市川親 交

(蚾早高等農林學校)

昭和 10 年 10 月 2 日受理

\begin{tabular}{|c|c|c|c|}
\hline & 目 & 次 & \\
\hline 第一章 & 緒 & & 關係 \\
\hline $\begin{array}{l}\text { 第二章 } \\
\text { 第一筫 }\end{array}$ & 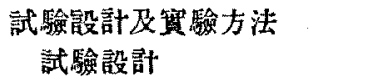 & 第六章 & $\begin{array}{l}\text { 要素單用こ石疢含有量この } \\
\text { 關係 }\end{array}$ \\
\hline $\begin{array}{l}\text { 第三䬣 } \\
\text { 第三節 }\end{array}$ & $\begin{array}{l}\text { 㸱 肥 量 } \\
\text { 移植, 管理及收潅 }\end{array}$ & 第七章 & $\begin{array}{l}\text { 要素單用こ燐酸含有䭪この } \\
\text { 關係 }\end{array}$ \\
\hline $\begin{array}{l}\text { 第四節 } \\
\text { 第三音 }\end{array}$ & 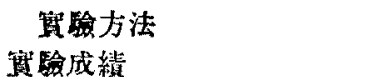 & 第入章 & 要素單用さ素含有量さの \\
\hline $\begin{array}{l}\text { 第二節 } \\
\text { 第二節 }\end{array}$ & $\begin{array}{l}\text { 生青調查成綪 } \\
\text { 牧䰹調查成綪 }\end{array}$ & 第九音 & $\begin{array}{l}\text { 姴素單用 } \\
\text { この岸水化物含有量 }\end{array}$ \\
\hline 第四章 & $\begin{array}{l}\text { 要素單用こ粐灰分含量さの } \\
\text { 關係 }\end{array}$ & $\begin{array}{l}\text { 第十章 } \\
\text { 第十一章 }\end{array}$ & 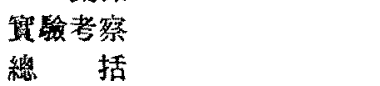 \\
\hline 第 五 㗬 & 露素單用さ硅酸含有量ミの & 第十二章 & 文 \\
\hline
\end{tabular}

\section{第一章 緒}

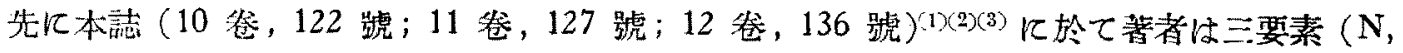

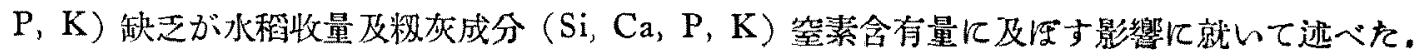
その娞要素 $(N, P, K, C a)$ 單用が水稻收量及粐灰成分 $(\mathrm{Si}, \mathrm{Ca}, \mathrm{P})$ 空素含有量，桨素含有量 に藷しく影響することを知つた。

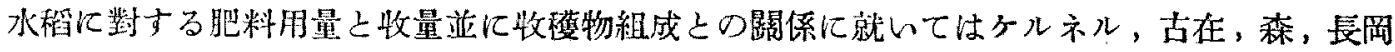
博士等4(5)によつて詳細に研究された。

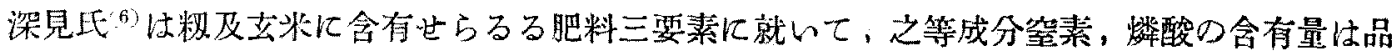

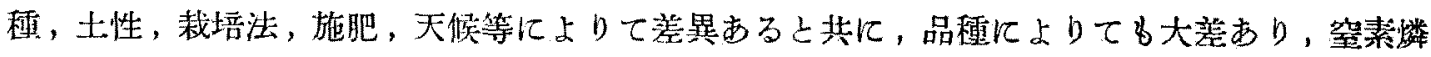
酸含有量により大䯣品種をも制じ得るここを述べられてるる。

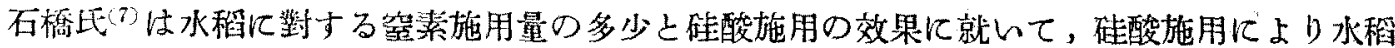

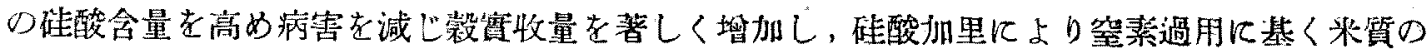
低下老防止し之れを優良ならしめることを報告してるられる。

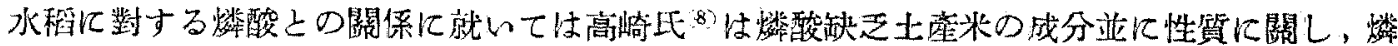

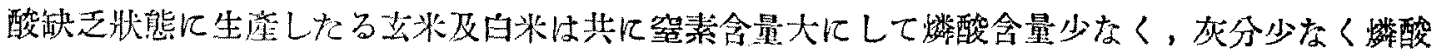
及苦土の少をい事老逃へられてるる。

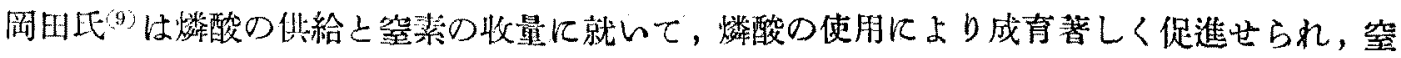

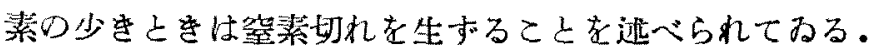




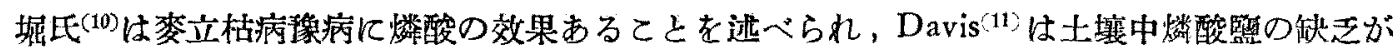

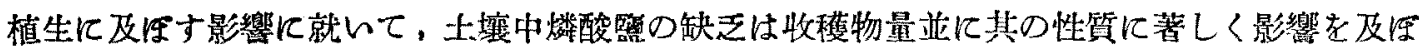
し，斯の如き土地に生じたる農作物等にて家音を盖ふ時，邓は人間が之を食する時は一種の榮 養不良症に陷る風土病に臛る場合ある事を述へられてるる。

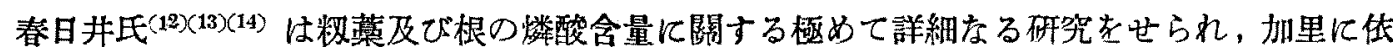

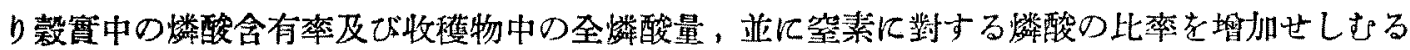
傾向あること述べられてるる。

水稳に對する加里との關係に就いては松木, 荒木兩氏 は水稻に對する加里肥料の效果に閣 する詳細なる研究を發表せられてるる。

小林，遠山兩氏 ${ }^{16}$ は小麥程の構造及粒形に及情す加里の作用に就いての成縝がある。Jacob (17)は收穫物の化學的組成に及你す加里肥料の影響に就いて興味ある研究をされてわる。

水稻に對する石灰との留係に就いては野村，坂井兩氏 18 の水程に對する石灰連用試驗成績， 水野 ${ }^{19)}$ ，深澤 ${ }^{(20)}$ の程作に對する石灰施用時期試驗に就いての研究あり。

石灰と植物生育其他の事項に就いては Ginsburg and Shive( 石灰及美の影響に就いての研究, Lipman, Blair and Prince ${ }^{(93)}$ は土壤及び牧椎物中の加里含

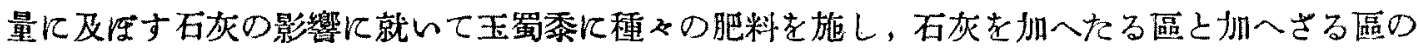
收擭物中の加里含量には著しい差異ある事を見，植物は石灰加里が豊富に供給せられたる場合 には加里を吸收することを明かにせられた。

Lipman and Blair(23) は大豆に石灰を施用したる時は種望の生举量を增加するのみならず，

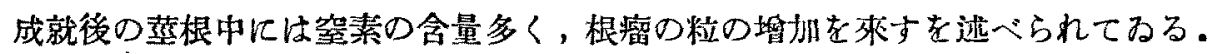

Parkar and Troug ${ }^{(24)}$ は石灰と空菜との間に一定の比がある如く雨者の比の低い 0.306 , 兩 者の比の高い 0.553 との二つに分け，前者は石灰の要求量少质〈土壤の酸性に對し抵抗力むり て草類之れに尿し，後者に屬する8のは壹科植物其他石灰の亚求量高き植物を含み，土埪の酸 性に對しては䥷なること孝述べられてるる。

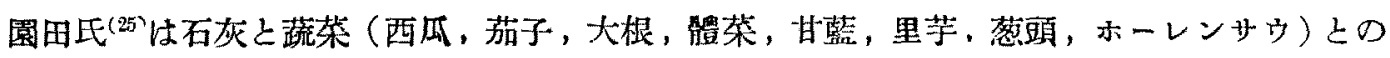
關係に就いての長年の研究成績を發表せられてるる。

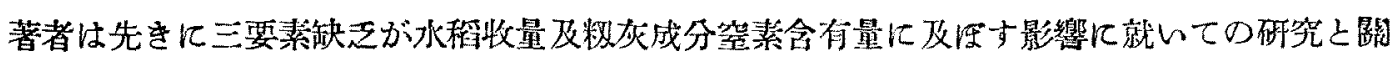

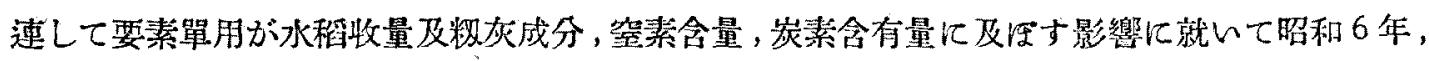
7 年, 8 年, 9 年度に於ける成績老訅して寥考に偕する。

\section{苐二龺 詰驗設計及苗駼方法}

$$
\text { 第一節 試 驗 設 計 }
$$

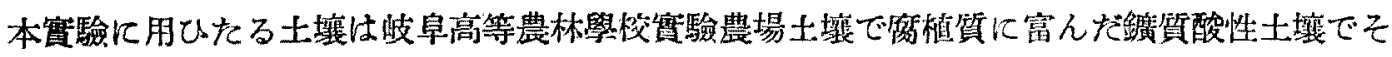
の化學的成分を見ると次の樣である。 
第 1 表 供試土褧化學的成分

\begin{tabular}{|c|c|c|c|c|c|c|c|}
\hline 成 & & 分 & 含 有 \% & 成 & 含 有 \% & 成 & 含 有 \% \\
\hline 水 & & 分 & 11.392 & \multirow{4}{*}{ 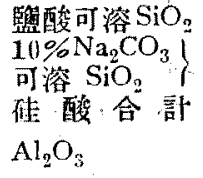 } & 0.234 & $\mathrm{MgO}$ & 0.131 \\
\hline 全 & 整 & 素 & 0.281 & & 12.118 & $\mathrm{~K}_{2} \mathrm{O}$ & 0.085 \\
\hline & 機 & 物 & 27.260 & & 12.352 & $\mathrm{Na}_{2} \mathrm{O}$ & 0.132 \\
\hline 監 & & 素 & 0.012 & & 8.990 & $\mathrm{P}_{2} \mathrm{O}_{5}$ & 0.088 \\
\hline 酸 & & 度 & 38.32 & $\mathrm{Fe}_{2} \mathrm{O}_{3}$ & 4.136 & \multirow{2}{*}{$\begin{array}{l}\mathrm{MnO} \\
\mathrm{SO}_{3}\end{array}$} & 0.091 \\
\hline & $\mathrm{pH}$ & & 5.54 & $\mathrm{CaO}$ & 0.117 & & 0.054 \\
\hline
\end{tabular}

實驗は反當二萬分の一ワダネル氏植木鉢に常法により風乾士壤 $10 \mathrm{~kg}$ 老填充した。 試驗區は次の4である。

1. $\mathrm{N}$ 單用區 空素索施し燐酸及加里を施さず。

2. P 單用區燐酸を施し窒素及加里を施さず.

3. $\mathrm{K}$ 單用區 加里老施し空素及燐酸を施さ和。

4. Ca單用區 石灰を施し空素，燐酸及加里を施さず。

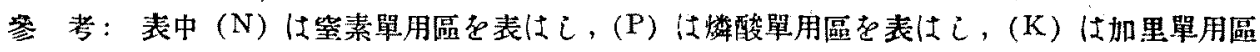

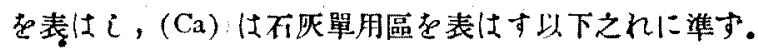

$$
\text { 第二節 施 肥 量 }
$$

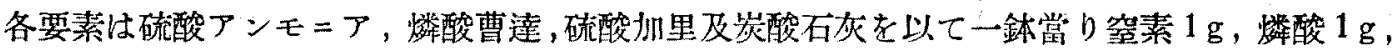
加里 $1 \mathrm{~g}$ ，岑酸石灰 $5 \mathrm{~g}$ 老施し，稳株は凡て每年之れを篩別し有機質肥料は一切添加せす。

$$
\text { 第三節 移植，管理及收檴 }
$$

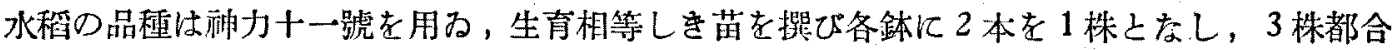
6本插秧し試驗は硝子室に於いて行ひ，且植物の生育に及疼す外界の條件を均一ならしむる樣 努力せり .

移植期は年により多少の相違あれども 7 月 1 日前後を標淮とし，收穫期は 11 月 5 日前後 とす.

收賟物は風乾狀態となして称量せり。

第四篩 惯 驗 方 法

本實驗は昭和 6 年度，7 年度，8 年度，9 年度の 4 ケ年の研究成續で，生育及收量調查は昭

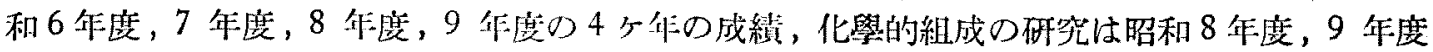
の 2 ケ年の成續である。

\section{第三章 惯 驗 成 績}

第一節 生育調查成綨

昭和 6 年, 7 年, 8 年, 9 年度の 4 ケ年の生育調䄳成績老示せば次表の如し。 
第 2 表生有調查成績

A. 昭和 6 年度成績

\begin{tabular}{|c|c|c|c|c|}
\hline 事 項 區 名 & $\mathrm{N}$ & $P$ & $\mathrm{~K}$ & $\mathrm{Ca}$ \\
\hline 草 丈 (cm) & 98 & 96 & 94 & 95 \\
\hline 分 葆 (本) & 65 & 36 & 35 & 37 \\
\hline 一株平均为薜 & 5.42 & 3.00 & 2.00 & 3.08 \\
\hline
\end{tabular}

B. 昭和 7 年度成樍

\begin{tabular}{|c|c|c|c|c|}
\hline 草 & 102 & 95 & 95 & 97 \\
\hline 分 蒘 (本) & 63 & 41 & 37 & 43 \\
\hline 一株平均分㷊 & 5.25 & 3.42 & 3.08 & 3.58 \\
\hline
\end{tabular}

\section{C. 昭和 8 年度成績}

\begin{tabular}{|c|c|c|c|c|}
\hline 草 妾 (cm) & 95 & 85 & 80 & 82 \\
\hline 分 璧 (本) & 47 & 39 & 43 & 35 \\
\hline 一株平均分獎 & 3.92 & 3.25 & 3.58 & 2.00 \\
\hline
\end{tabular}

D. 昭和 9 年度成績

\begin{tabular}{|c|c|c|c|c|}
\hline 草 丈 (cm) & 95 & 95 & 92 & 93 \\
\hline 分 菜 （本） & 40 & 24 & 27 & 26 \\
\hline 一粎本均分蔡 & 3.33 & 2.00 & 2.25 & 2.24 \\
\hline
\end{tabular}

E. 4 ケ年平均成績

\begin{tabular}{|c|c|c|c|c|}
\hline 草 艾 (cm) & 96 & 95 & 90 & 92 \\
\hline 分 璧 (本) & 54 & 35 & 36 & 35 \\
\hline 一株平均妿㜀 & 4.50 & 3.00 & 3.00 & 3.00 \\
\hline
\end{tabular}

第 3 表 各區に對する比較成績

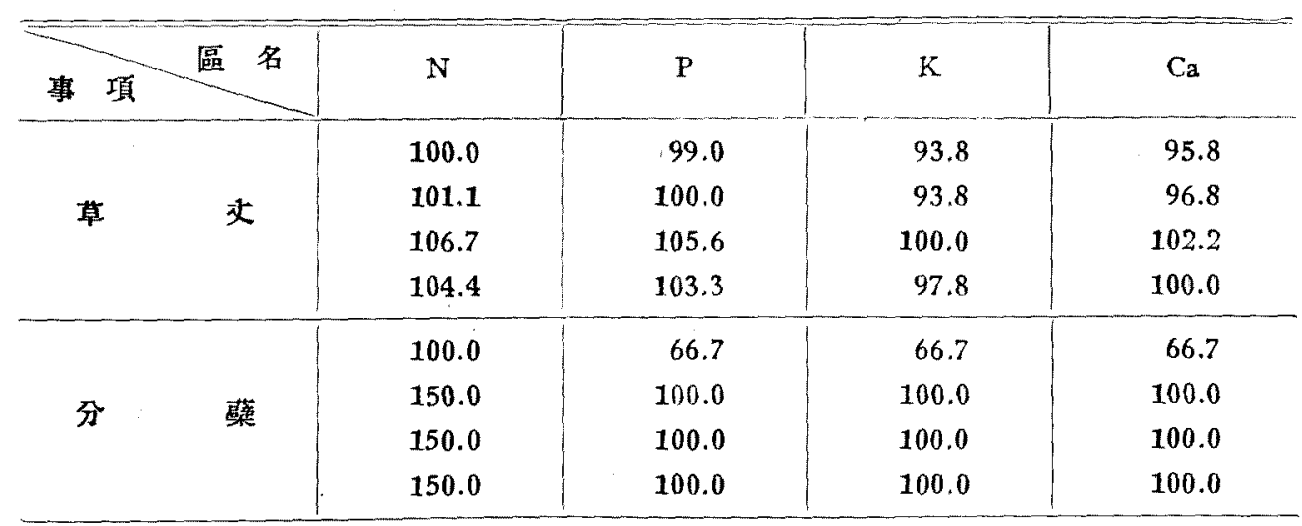

第 2 表及第 3 表によれば水葐の草丈は 90〜96 cm にて加里單用區（空素及燐酸缺之區）最短 で次いで石灰單用區（窒素，燐酸及加里缺乏區），燐酸單用區（䇪素及加里缺之區）の順で窒素 


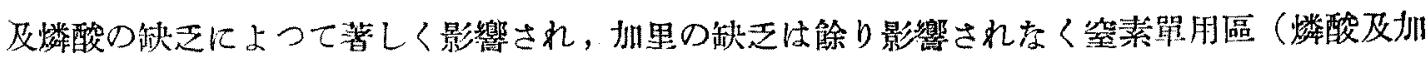
里缺乏區）最高であつた。

一本の分萩平均は 3.00〜 4.50本にて燐酸單用區, 加里單用區, 石灰單朋區共に同し結果を示 した.

$$
\text { 第二節 收量調棑成績 }
$$

昭和 6 年, 7 年, 8 年, 9 年度の 4 ケ年の收量調查成績を示せば次表の如し。

第 4 表 收量調查成續

A. 昭和 6 年度成績

\begin{tabular}{|c|c|c|c|c|}
\hline 事 项 壆 名 & $\mathrm{N}$ & $\mathrm{P}$ & $\mathrm{K}$ & $\mathrm{Ca}$ \\
\hline 全電量 $(g)$ & 88.0 & 56.0 & 65.0 & 56.0 \\
\hline 粐 量 $(\mathrm{g})$ & 43.0 & 23.0 & 26.0 & 25.0 \\
\hline 莜 量（g） & 45.0 & 33.0 & 39.0 & 31.0 \\
\hline
\end{tabular}

B. 昭和 7 年度成䋶

\begin{tabular}{ll|l|l|l|l} 
全 & 雷 量 $(\mathrm{g})$ & 84.0 & 76.0 & 77.0 & 75.0 \\
粐 & 量 $(\mathrm{g})$ & 35.0 & 32.0 & 30.0 & 37.0 \\
繁 & 量 $(\mathrm{g})$ & 49.0 & 44.0 & 47.0 & 38.0 \\
\hline
\end{tabular}

C. 昭和 8 年度成續

\begin{tabular}{ll|l|l|l|l} 
全 & 量 $(\mathrm{g})$ & 84.0 & 71.0 & 66.0 & 83.0 \\
粐 & 量 $(\mathrm{g})$ & 40.0 & 34.0 & 32.0 & 42.0 \\
涑 & 量 $(\mathrm{g})$ & 44.0 & 37.0 & 34.0 & 41.0 \\
\hline
\end{tabular}

D. 昭和 9 年度成績

\begin{tabular}{ll|l|l|l|l}
\hline 全重 $(\mathrm{g})$ & 64.0 & 75.0 & 75.0 & 83.0 \\
粐 & 量 $(\mathrm{g})$ & 16.0 & 32.0 & 33.0 & 37.0 \\
蘶 & 量 $(\mathrm{g})$ & 48.0 & 43.0 & 42.0 & 45.0 \\
\hline
\end{tabular}

E. 4 万年平均成綪

\begin{tabular}{|c|c|c|c|c|}
\hline 全重量 $(\mathrm{g})$ & 80.0 & 69.5 & 71.0 & 74.0 \\
\hline 粐 量 $(\mathrm{g})$ & 33.5 & 30.0 & 30.0 & 35.0 \\
\hline 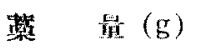 & 46.5 & 39.5 & 41.0 & 39.0 \\
\hline
\end{tabular}

第 5 表 各區に對する比較成績

\begin{tabular}{|c|c|c|c|c|}
\hline 事 項 媐 名 & $N$ & $P$ & $\mathrm{~K}$ & $\mathrm{Ca}$ \\
\hline 全 重 量 & $\begin{array}{l}100.0 \\
125.1 \\
112.7 \\
108.1\end{array}$ & $\begin{array}{r}86.9 \\
100.0 \\
97.9 \\
93.9\end{array}$ & $\begin{array}{r}88.8 \\
102.2 \\
100.0 \\
96.0\end{array}$ & $\begin{array}{r}92.5 \\
106.5 \\
104.2 \\
100.0\end{array}$ \\
\hline
\end{tabular}




\begin{tabular}{|c|c|c|c|c|c|}
\hline \multirow{4}{*}{ 粉 } & \multirow{4}{*}{ 量 } & 100.0 & 89.6 & 89.6 & 104.5 \\
\hline & & 111.7 & 100.0 & 100.0 & 116.7 \\
\hline & & 111.7 & 100.0 & 100.0 & 116.7 \\
\hline & & 95.7 & 85.7 & 85.7 & 100.0 \\
\hline \multirow{4}{*}{ 潞 } & \multirow{4}{*}{ 量 } & 100.0 & 84.9 & 88.2 & 83.9 \\
\hline & & 117.7 & 100.0 & 103.8 & 98.7 \\
\hline & & 113.4 & 96.3 & 100.0 & 95.1 \\
\hline & & 119.2 & 101.3 & 105.1 & 100.0 \\
\hline
\end{tabular}

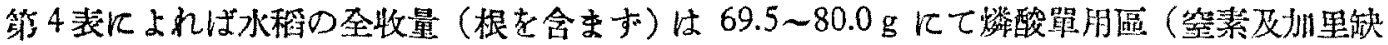
乏區）は最少で，次いで加里單用區（䇪素及燐酸缺泛區）で石灰單用區は燐酸及加里單朋區に 比し多い。乙れ石灰加里に上つて土裹中の不可給態成分が可給態成分に分解されをるものなら 九か (後进)，窒素單用區（燐酸及加里缺乏區）最高老示した。

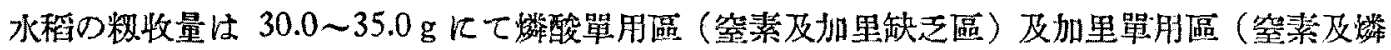
酸缺乏區）は最少で，次いで空素單用區（燐酸及加里缺乏區），石灰單用區最高寺示した。

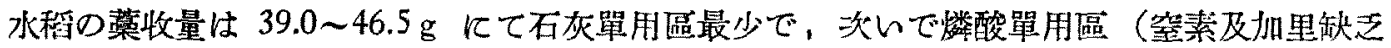
區），加里單用區（窒素及燐酸缺乏區）の順で殆んど大差なく，窒素單用區（燐酸及加里缺乏 區）最高省した。

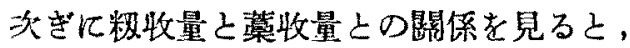

第 6 表 粐量と葢量との比

\begin{tabular}{c|c|c|c|c|c}
\hline 事項 & 區 & $\mathrm{N}$ & $\mathrm{g}$ & $\mathrm{K}$ & $\mathrm{Ca}$ \\
\hline 粐 & 箱 & 1.39 & 1.32 & 1.37 & 1.11 \\
\hline & & 1.00 & 0.95 & 0.99 & 0.80 \\
& 1.05 & 1.00 & 1.04 & 0.84 \\
各區の比較 & 1.01 & 0.96 & 1.00 & 0.81 \\
& 1.25 & 1.19 & 1.23 & 1.00 \\
\hline
\end{tabular}

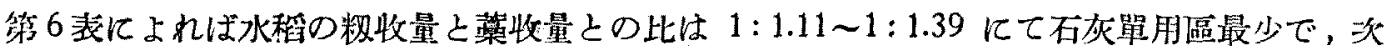
レで燐酸單用區（空素及加里缺乏區）加里單用區（窒素及燐酸缺乏區）の順で窒素單用區（燐 酸加里缺乏區）最大を示してるる.今之等兩者の關係を見るに窒素を施すととによつて全收量

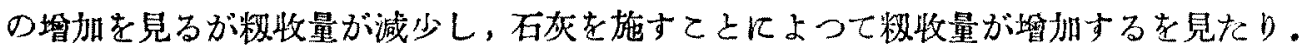

\section{第 四 章 要素單用と粐灰分含量との關保}

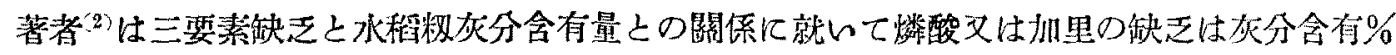
を減少せしむるてとを諳いた。

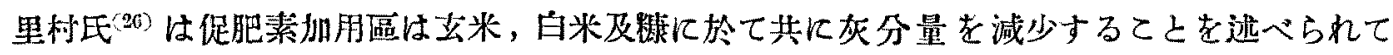
みる。 
Nehring ${ }^{27}$ は，禾本科に於ては土壤反應を酸性より中性に移行さす事によつて灰分量を增加 すること，又收穫量が減少した場合に灰分量が增加するてとを庇べられてるる。

今恕に要素單用が粑灰分合有％に如何なる影響があるかを見れば次の樣である。 第 7 表 灰分含量及各區に對する比較

\begin{tabular}{|c|c|c|c|c|}
\hline 事 項 覀 名 & $\mathrm{N}$ & $\mathrm{P}$ & K & $\mathrm{Ca}_{2}$ \\
\hline 死分 鼌 $(\%)$ & 4.542 & 3.209 & 2.874 & 2.990 \\
\hline \multirow{4}{*}{ 戻 分 比 較 } & 100.0 & 70.7 & 63.3 & 65.8 \\
\hline & 141.5 & 100.0 & 89.6 & 93.2 \\
\hline & 158.1 & 111.7 & 100.0 & 104.0 \\
\hline & 151.9 & 107.3 & 96.1 & 100.0 \\
\hline
\end{tabular}

第7 表によれば粐灰分％は $2.874 〜 4.542 \%$ 飞て加里單用區（窒素及燐酸缺乏區）最少で， 次いで石灰單朋區，燐酸單用區（空素及加里缺乏區）の順で窒素單用區（燐酸及加里缺乏區） 最高を示してるる。乙れ窒菜單用區產の最高を示してるるのは去米の Compact ならさるに比 し，加里單用區及石灰單用區產の少ないのは去米の Compact なるととが考へられる。 向ての灰分含有量を要素缺巨區産の椟灰分含有量と比較して見ると次の㥞である。

第 8 表 肥料要素之灰分量並各區之の比較

\begin{tabular}{|c|c|c|c|c|c|c|c|c|c|}
\hline 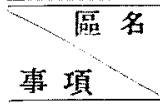 & N.P.K & P. $\mathrm{K}$ & N. K & N. P & Non. M & $N$ & $\mathrm{P}$ & $\mathrm{K}$ & $\mathrm{Ca}$ \\
\hline 戻分 $(\%)$ & 3.306 & 4.011 & 3.555 & 3.289 & 4.122 & 4.542 & 3.209 & 2.874 & 2.990 \\
\hline \multirow{3}{*}{ 各 } & 100.0 & 121.3 & 107.5 & 99.5 & 124.7 & 137.4 & 97.1 & 86.9 & 90.4 \\
\hline & 82.4 & 100.0 & 88.6 & 82.0 & 102.8 & 112.7 & 80.0 & 71.7 & 74.5 \\
\hline & 93.0 & 112.8 & 100.0 & 92.5 & 115.9 & 127.8 & 90.3 & 80.8 & 84.1 \\
\hline 區 & 100.5 & 122.0 & 108.1 & 100.0 & 125.3 & 138.1 & 97.6 & 87.4 & 90.9 \\
\hline の & 80.2 & 97.3 & 86.2 & 79.8 & 100.0 & 110.2 & 77.9 & 69.7 & 72.5 \\
\hline \multirow{2}{*}{ 比 } & 72.8 & 88.3 & 78.3 & 72.4 & 90.8 & 100.0 & 70.7 & 63.3 & 65.8 \\
\hline & 103.0 & 125.0 & 110.8 & 102.5 & 128.5 & 141.5 & 100.0 & 89.6 & 93.2 \\
\hline \multirow[t]{2}{*}{ 较 } & 115.0 & 139.6 & 123.7 & 114.4 & 143.4 & 158.1 & 111.7 & 100.0 & 104.0 \\
\hline & 110.6 & 134.1 & 118.9 & 110.0 & 137.9 & 151.9 & 107.3 & 96.1 & 100.0 \\
\hline
\end{tabular}

\section{第 五 章＼cjkstart要素單用と硅酸含有量との關保}

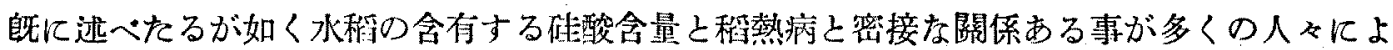
つて研究された。

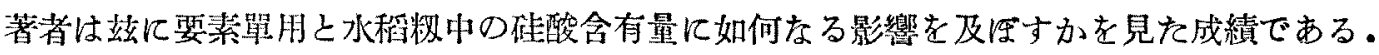
第 9 表 籾硅酸含量及各區に對する比較

\begin{tabular}{|c|c|c|c|c|}
\hline 事 項 區 名 & $N$ & $P$ & $\mathrm{~K}$ & $\mathrm{Ca}$ \\
\hline 礁酸责 $(\%)$ & 74.745 & 68.432 & 70.839 & 58.564 \\
\hline
\end{tabular}




\begin{tabular}{c|r|r|r|r|r}
\hline & 100.0 & 91.6 & 94.8 & 78.4 \\
109.2 & 100.0 & 103.5 & 85.6 \\
105.5 & 96.6 & 100.0 & 82.7 \\
127.6 & 116.6 & 121.0 & 100.0 \\
\hline
\end{tabular}

第9表によれば粐灰分中の倠酸合有量は 58.564〜74.745\%にて石灰單用區商は最少で，次い

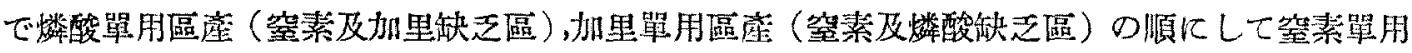

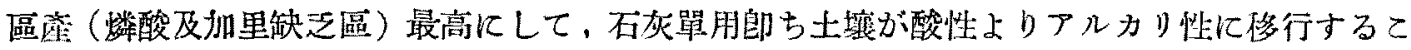
とによつて住酸の吸收が減少せしbのならんか，燐酸單用朗ち燐酸を多量に施す場合には扠里 單用師ち加里を多量に施す場合よりも硅酸の吸收が少ない様でする。

向この灰分中の住酸含有量老要素缺乏區產の灰分中の礁酸含有量と比較して見ると次の樣で ある。

第 10 表 肥料要素と碓酸含量䒚各區上の比較

\begin{tabular}{|c|c|c|c|c|c|c|c|c|c|}
\hline 求项 & N. P. K & P. $K$ & $N . K$ & N. P & Non. $M$ & $N$ & $P$ & $\mathrm{~K}$ & $\mathrm{Ca}$ \\
\hline $\mathrm{SiO}_{2}(\%)$ & 52.063 & 63.605 & 64.556 & 56.922 & 67.009 & 74.745 & 68.432 & 70.839 & 58.564 \\
\hline \multirow{3}{*}{ 砤 } & 100.0 & $1: 2.2$ & 124.0 & 109.3 & 128.7 & 143.6 & 131.4 & 136.1 & 112.5 \\
\hline & 81.9 & 100.0 & 101.5 & 89.5 & 105.4 & 117.5 & 107.6 & 111.4 & 92.1 \\
\hline & 80.6 & 98.5 & 100.0 & 109.3 & 103.8 & 115.8 & 106.0 & 109.7 & 90.7 \\
\hline 酸 & 91.5 & 111.7 & 113.4 & 100.0 & 117.7 & 131.3 & 120.2 & 124.4 & 102.9 \\
\hline の & 77.7 & 94.9 & 96.3 & 84.9 & 100.0 & 111.5 & 102.1 & 105.7 & 87.4 \\
\hline \multirow[t]{2}{*}{ 比 } & 69.7 & 85.1 & 86.4 & 76.2 & 89.7 & 100.0 & 91.6 & 94.8 & 78.4 \\
\hline & 76.1 & 92.9 & 94.3 & 83.2 & 97.9 & 109.2 & 100.0 & 103.5 & 85.6 \\
\hline \multirow{2}{*}{ 較 } & 73.5 & 89.8 & 91.1 & 80.4 & 94.6 & 105.5 & 96.6 & 100.0 & 82.7 \\
\hline & 88.9 & 108.6 & 110.2 & 97.2 & 114.4 & 127.6 & 116.8 & 121.0 & 100.0 \\
\hline
\end{tabular}

\section{第 六 章 要素單用と灰分含有量との繴係}

石灰の植物に對する生理的作用並びに土墥に對する理化學的作用に就いては多くの業績が ある。

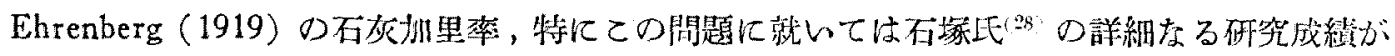
疆表された。

既に述べをるが如く Blair and McLean ${ }^{(29)}$, Lipman and Blair(:0), Parker and Truog ${ }^{(2)}$ ，

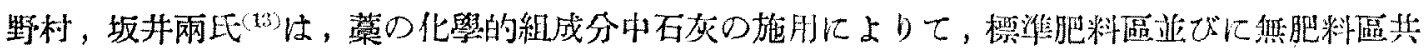

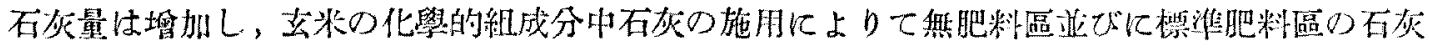
量の增加を氷えすととを连べられてるる。

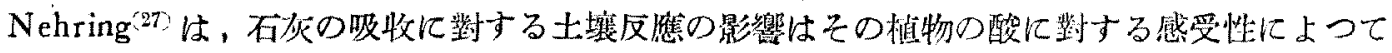
自ら變化するが, 酸よりアルカリ性に趣くに從つて前者は不灰の含量を多少坦加するが，後者 
は石灰を相當多量必要とし，植物の種々なる生理的作用は反應に龂する感受性と密接な關係を 有すること述へられてるる。

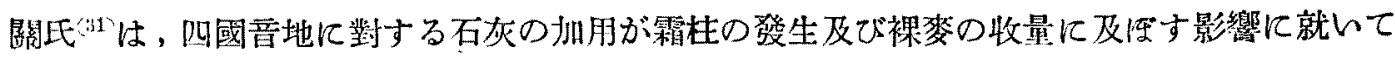
の記事がある。

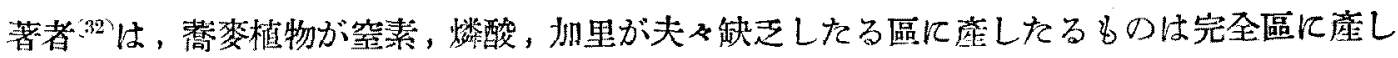
たる8のに比して石灰の攝取量が多いことを見た。

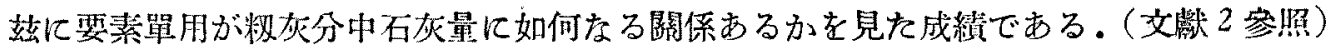

第 11 表 石灰含量及各區に對する比較

\begin{tabular}{|c|c|c|c|c|}
\hline 事 項‥嵒 名 & $\mathrm{N}$ & $\mathrm{P}$ & $\mathrm{K}$ & $\mathrm{Ca}$ \\
\hline 不欧昷(\%) & 3.450 & 4.324 & 4.388 & 4.924 \\
\hline \multirow{4}{*}{ 石医比較 } & 100.0 & 125.3 & 127.2 & 142.7 \\
\hline & 79.8 & 100.0 & 101.5 & 113.9 \\
\hline & 78.6 & 98.5 & 100.0 & 112.2 \\
\hline & 70.1 & 87.8 & 89.1 & 100.0 \\
\hline
\end{tabular}

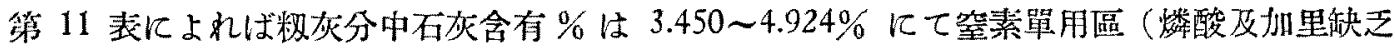

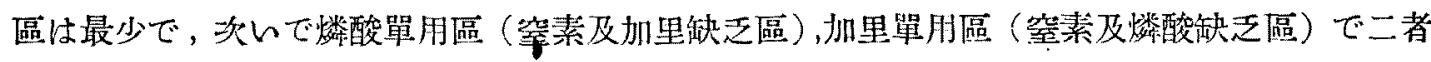
多笲ざ美がく，石灰單用區は最高である。

石灰の吸收量は空素及加里の缺乏，峌素及燐酸の缺乏は妩程影響して居ないが，燐酸及加里 の缺乏によつて減少することが見受けられる。

抬この灰分中の石灰含有量を要素缺王區产の灰分中の石灰含有量と比較して見る上次の㥞で ある。

第 12 表 肥料要素と石灰含量並各區との比較

\begin{tabular}{|c|c|c|c|c|c|c|c|c|c|}
\hline 區名 & $\mathrm{N}, \mathrm{P}, \mathrm{K}$ & P. K & N. K & N. P & Non. M & N & $\mathrm{P}$ & K & $\mathrm{Ca}$ \\
\hline $\mathrm{CaO}(\%)$ & 5,250 & 4.156 & 3.939 & 5.805 & 2.623 & 3.450 & 4.324 & 4.388 & 4.924 \\
\hline \multirow{3}{*}{ 不 } & 100.0 & 79.2 & 75.0 & 110.6 & 50.0 & 65.7 & 82.4 & 83.6 & 93.8 \\
\hline & 126.3 & 100.0 & 94.8 & 139.7 & 63.1 & 83.0 & 104.0 & 105.6 & 118.5 \\
\hline & 133.3 & 105.5 & 100.0 & 147.4 & 66.6 & 87.6 & 109.8 & 111.4 & 125.0 \\
\hline 此 & 90.4 & 71.6 & 67.9 & 100.0 & 45.2 & 59.4 & 74.5 & 75.6 & 84.8 \\
\hline の & 200.0 & 158.4 & 150.2 & 221.3 & 100.0 & 131.5 & 164.8 & 167.3 & 187.7 \\
\hline \multirow{2}{*}{ 比 } & 152.2 & 120.5 & 114.2 & 168.3 & 76.0 & 100.0 & 125.3 & 127.2 & 142.7 \\
\hline & 121.0 & 96.1 & 91.1 & 134.3 & 60.7 & 79.8 & 100.0 & 101.5 & 113.9 \\
\hline \multirow{2}{*}{ 较 } & 119.6 & 94.7 & 89.8 & 132.3 & 59.8 & 78.6 & 98.5 & 100.0 & 112.2 \\
\hline & 106.6 & 84.4 & 80.8 & 117.9 & 53.3 & 70.1 & 87.8 & 89.1 & 100.0 \\
\hline
\end{tabular}




\section{第 七 章 要素單用と燐酸含有量との關係}

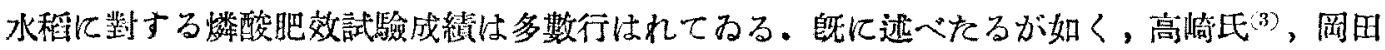

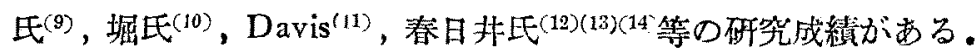

Pfeiffer, Blanck, Simmer and Rathmann ${ }^{(3)}$ は, 土襄中䅈分量の決定に關し，植物が鶖肥料

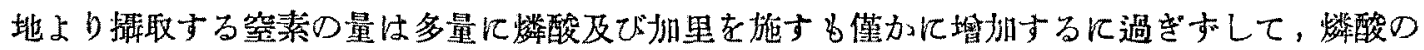

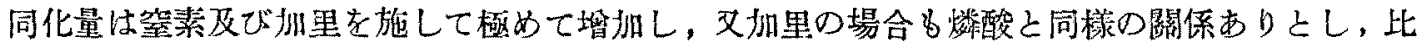

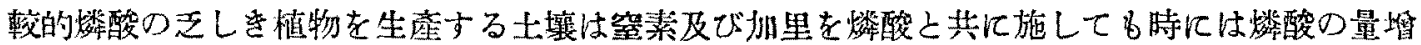
加するか，若くは增拟せざることあると，植物中磷酸の量比较的多量几增加するには醉酸肥料 を施した場合にある事を述べられてるる。

小堀氏

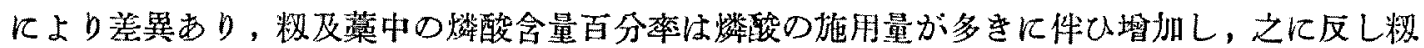
中の窒素含有百分率は減少する。麥類を栽培するに當りては適賞なる品種を選ぶてとによりて 不溶燐酸を多く利用し得へく，種望の燐酸含量百分率は燐酸の施用量多をに件ひ壖加し，之に 反し㮫素合量百分率は減少するてと迅べられてるる。

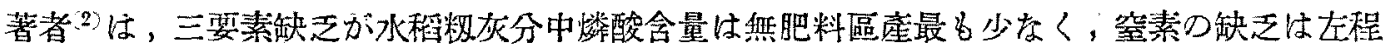

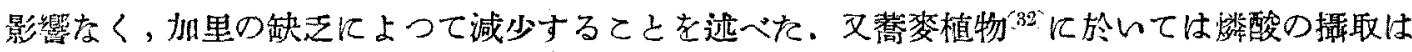

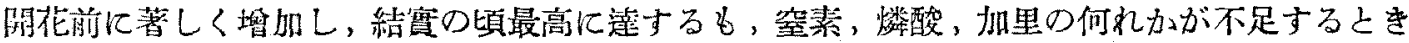
は燐酸の攝取量よりる石灰の攝取量が多くなるととを書いた。

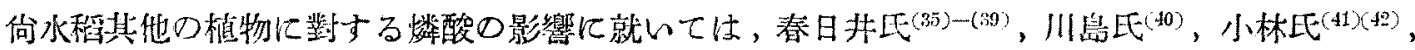

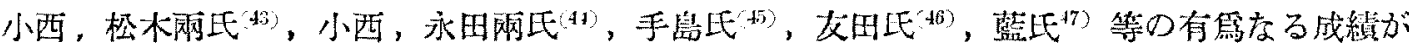
ある。

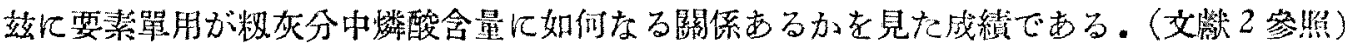

第 13 表 裙酸含量及各區に對する比較

\begin{tabular}{c|c|c|c|c}
\hline 事項 & $\mathrm{N}$ & $\mathrm{P}$ & $\mathrm{K}$ & $\mathrm{Ca}$ \\
\hline $\mathrm{P}_{2} \mathrm{O}_{5}(\%)$ & 2.701 & 3.458 & 3.968 & 2.523 \\
\hline & 100.0 & 128.0 & 146.9 & 93.4 \\
\hline \multirow{3}{*}{ 橉 酸 比較 } & 78.1 & 100.0 & 114.7 & 73.0 \\
& 68.1 & 87.1 & 100.0 & 63.6 \\
& 107.1 & 137.1 & 157.3 & 100.0
\end{tabular}

第 13 表によれば粐灰分中の燐酸含有量は 2.523〜3.968\%にて石灰單用區は最少で，次いで

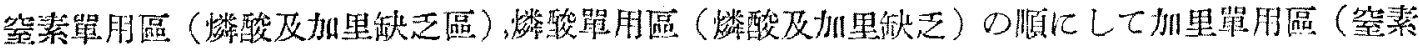
及燐酸缺乏區）最高を示せり。 
加里單朋區郎ち加里を多量に施用した場合には燐酸單朋區郎ち燐酸を多量に施用した場合より も燐酸含有量を增加するを見る。

石灰單用區郎ち石灰を多量に施用した場合には燐酸單用區郎ち燐酸を多量に施した場合上り も燐酸含有量を減少を來をした。乙れ酸性に讶い植物例入ばチモシー，クロバー類では燐酸含 有量は石灰の施用によつて增加すると言れてるるが，水程に於いては之れに反し減少してねる が植物の酸に對する感不感性によるものならんか。

少ての灰分中の燐酸含有量を型素缺乏區產の扊分中の燐酸含有量と比較して見ると次の樣で ある。

第 14 表 肥料要絜と燐酸含量並各區との比較

\begin{tabular}{|c|c|c|c|c|c|c|c|c|c|}
\hline 區名 & N.P.K & P. K & $\mathrm{N}, \mathrm{K}$ & N.P & Non, M & $\mathrm{N}$ & $P$ & K & $\mathrm{Ca}$ \\
\hline $\mathrm{P}_{2} \mathrm{O}_{5}(\%)$ & 6.768 & 5.335 & 4.209 & 4.746 & 1.803 & 2.701 & 3.458 & 3.968 & 2.523 \\
\hline \multirow{3}{*}{ 燐 } & 100.0 & 78.7 & 62.2 & 70.1 & 26.6 & 39.9 & 51.1 & 58.6 & 37.3 \\
\hline & 78.8 & 190.0 & 78.9 & 89.0 & 33.8 & $: 0.6$ & 64.8 & 74.4 & 47.3 \\
\hline & 160.8 & 126.8 & 100.0 & 112.8 & 42.8 & 64.2 & 82.2 & 94.3 & 59.9 \\
\hline 酸 & 142.6 & 112.4 & 88.7 & 100.0 & 38.0 & 56.9 & 72.9 & 83.6 & 53.2 \\
\hline D & 375.4 & 295.9 & 233.4 & 263.2 & 100.0 & 144.8 & 191.8 & 220.1 & 139.9 \\
\hline \multirow[t]{2}{*}{ 比 } & 250.6 & 197.5 & 155.8 & 175.7 & 66.8 & 100.0 & 125.0 & 146.9 & 93.4 \\
\hline & 195.7 & 154.3 & 121.7 & 137.2 & 52.1 & 78.1 & 100.0 & 114.7 & 73.0 \\
\hline \multirow[t]{2}{*}{ 噧 } & 170.6 & 134.5 & 106.1 & 119.6 & 45.4 & 68.1 & 87.1 & 100.0 & 63.6 \\
\hline & 268.3 & 211.5 & 166.8 & 188.1 & 71.5 & 107.1 & 137.1 & 157.3 & 100.0 \\
\hline
\end{tabular}

\section{第 八 章 要素單用と窒素含有量との關係}

水稻に對する空素賀肥料の肥效試驗成䋶に就いては非常に多く，特に水稻の含有する住酸量

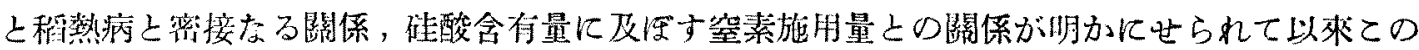
研究が行れる栐になつた。

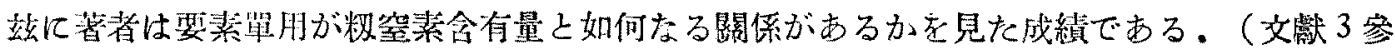
哭)

第 15 表 空素含量及各區に對する比较

\begin{tabular}{|c|c|c|c|c|}
\hline 牙 項 凅 & $\mathrm{N}$ & $\mathrm{P}$ & K & $\mathrm{Ca}$ \\
\hline 喾 䇣 $(\%)$ & 1.941 & 1.108 & 1.097 & 1.000 \\
\hline \multirow{4}{*}{ 筀素此㜞 } & 100.0 & 57.1 & 51.9 & 51.5 \\
\hline & 175.2 & 100.0 & 90.9 & 90.3 \\
\hline & 192.8 & 110.0 & 100.0 & 99.3 \\
\hline & 194.1 & 110.8 & 100.7 & 100.0 \\
\hline
\end{tabular}

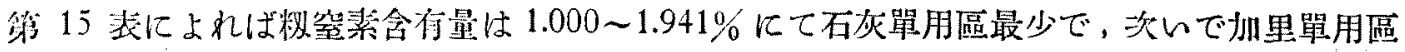




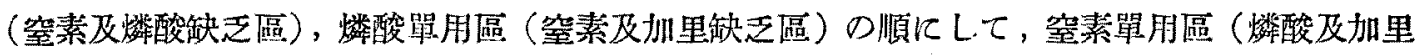
缺乏區）最高を示した。

窒素の吸收量は空素を施用せす机燐酸，扣里，石灰の一成分のみを多量に施用与る場合には 殆んど差異がなく，燐酸を多量に施用する場合には加里を多量に施用する場合上りる稍々多く 窒素を吸收する樣である。

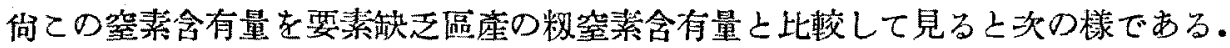

第 16 表 肥料要素と空素含量並各區との比較

\begin{tabular}{|c|c|c|c|c|c|c|c|c|c|}
\hline 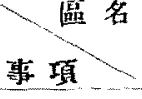 & N.P. K & P. K & N. K & N. P & Non, $M$ & $\mathrm{~N}$ & $\mathbf{P}$ & $\mathrm{K}$ & $\mathrm{Ca}$ \\
\hline 等素 $(\%)$ & 0.926 & 0.819 & 0.929 & 1.204 & 0.728 & 1.941 & 1.108 & 1.007 & 1.000 \\
\hline \multirow{3}{*}{ 堂 } & 100.0 & 88.4 & 100.3 & 130.0 & 78.6 & 209.6 & 119.7 & 108.7 & 108.0 \\
\hline & 113.1 & 100.0 & 113.4 & 147.0 & 88.9 & 237.0 & 135.3 & 123.0 & 122.1 \\
\hline & 99.7 & 88.2 & 100.0 & 129.6 & 78.4 & 208.9 & 119.3 & 108.4 & 107.6 \\
\hline 素 & 76.9 & 68.0 & 77.2 & 100.0 & 60.5 & 161.2 & 92.0 & 83.6 & 83.1 \\
\hline 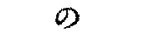 & 127.2 & 112.5 & 127.6 & 165.4 & 100.0 & 266.6 & 152.2 & 138.3 & 137.4 \\
\hline \multirow{2}{*}{ 此 } & 47.7 & 42.2 & 47.9 & 62.0 & 37.5 & 100.0 & 57.1 & 51.9 & 51.5 \\
\hline & 83.6 & 73.9 & 83.8 & 108.7 & 65.7 & 175.2 & 100.0 & 90.9 & 90.3 \\
\hline \multirow[t]{2}{*}{ 輘 } & 92.0 & 81.3 & 92.3 & 119.6 & 72.3 & 192.8 & 110.0 & 100.0 & 99.3 \\
\hline & 92.6 & 81.9 & 92.9 & 120.4 & 72.8 & 194.1 & 110.8 & 100.7 & 100.0 \\
\hline
\end{tabular}

芽九䓥 要素單用と炭水化物含有量との䵇係

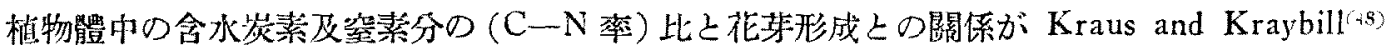
によつて化學的及理諭的に研究せられ，光等の消息が明にせられて以本ての研究が行れる㥞に 李つた。

元隶果樹截培の目的は果䁈の生產であつて花芽の着生は其先決問題にして，剪定，整枝，噍 水，日照特間の長短，施肥等の合理的作菜によつて其目的が淩せられるのである。

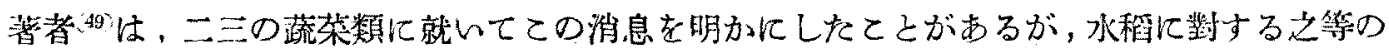
研究は多しとせ和。

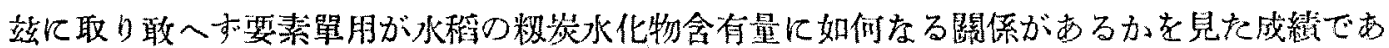

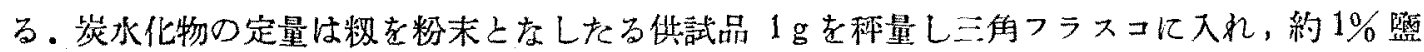

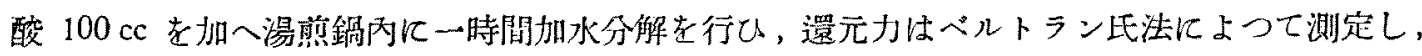
全炭水化物 glucose として表はし，份 carbonの量は glucose から算出した。

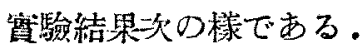

第 17 表 炭水化物（glucose）含量及各區に對する比較

\begin{tabular}{c|c|c|c|c}
\hline 專 項 眳 名 & $\mathrm{N}$ & $\mathrm{P}$ & $\mathrm{K}$ & $\mathrm{Ca}$ \\
\hline glucose $(\%)$ & 11.469 & 17.368 & 19.044 & 17.334 \\
\hline
\end{tabular}




\begin{tabular}{l|r|r|r|r}
\hline & 100.0 & 151.4 & 166.0 & 151.1 \\
glucose 比較 & 66.0 & 100.0 & 109.6 & 99.8 \\
& 60.2 & 91.2 & 100.0 & 91.0 \\
& 66.2 & 100.2 & 109.9 & 100.0 \\
\hline
\end{tabular}

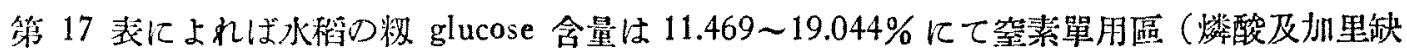
乏區）最少で，次いで石灰單用區，燐酸單用區（窒素及加里缺乏區）の順にして二者殆ど大美 なく，加里單用區（窒素及燐酸缺乏區）最高走示した。

炎水化物の生成は窒素單用的ち䇪素を多量に施用することによつて減少し，三要素を施用せ すして石灰のみ施用した場合に於いても燐酸單用郎ち燐酸を多量に施用した區と多ど變らない が植物體中にて石灰は䨽水化物の移轉に必要なためならん。

加里を多量に施用した場合に炭水化物を著しく增加してるるが，加里が植物體中に於いて炭 水化物の生成に必要なることが古くから知られてるる。最近 Hellriegel and Wilfart (1928) が，馬鈴著，禾貒類，甜荣等で筫驗を行ひ澱粉，糖分の量は加里の用量に件つて增加すること を述べてるる。

次ぎ装素單用と炭素率との關係老見ると次の樣である。

第 18 表 岑素率及各區に對する比較

\begin{tabular}{|c|c|c|c|c|}
\hline 等 項 區 名 & $\mathbf{N}$ & $P$ & $\mathbf{K}$ & $\mathrm{Ca}$ \\
\hline Carbon $(\%)$ & 4.588 & 6.947 & 7.618 & 6.934 \\
\hline 炭 素 率 & 236 & 6.27 & 7.56 & 6.93 \\
\hline \multirow{4}{*}{ 宸素比较 } & 100.0 & 265.3 & 320.0 & 273.2 \\
\hline & 37.7 & 100.0 & 120.6 & 100.5 \\
\hline & 31.3 & 82.9 & 100.0 & 91.6 \\
\hline & 34.1 & 91.0 & $10) .1$ & 100.0 \\
\hline
\end{tabular}

\section{第十章 實 驗 考 察}

既汇述べたるが如く肥料要素單用 $(\mathrm{N}, \mathrm{P}, \mathrm{K}, \mathrm{Ca})$ が水稻の草丈，分菜，粦灰分量及び灰成

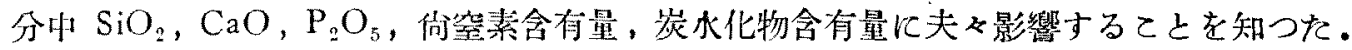

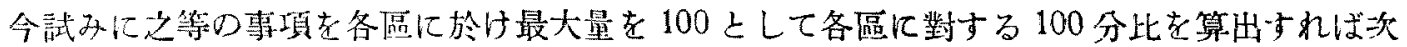
の栐である。

第 19 表 生育及收量との相關關係

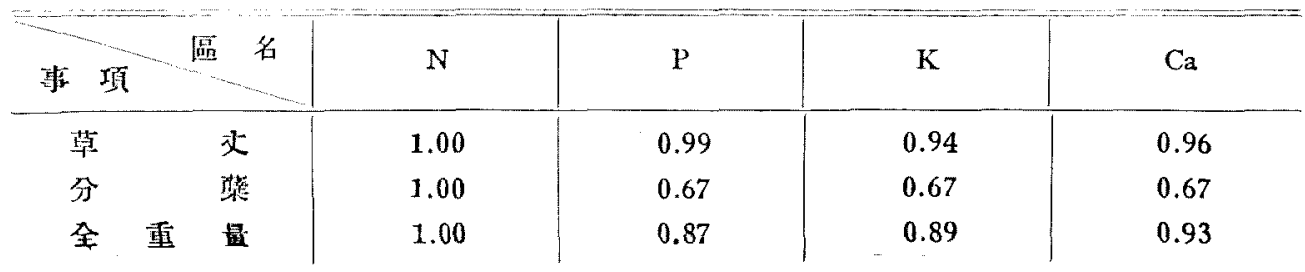




\begin{tabular}{rrr|l|l|l|l} 
粐 & 重 & 量 & 0.96 & 0.86 & 0.86 & 1.00 \\
涤 & 重 & 最 & 1.00 & 0.85 & 0.88 & 0.84 \\
平 & & 坞 & 0.99 & 0.85 & 0.85 & 0.88 \\
\hline
\end{tabular}

第 19 表に見るが如く生有及び收量の肥料要素虽朋との關係は空素及加里の缺乏，窒素及燐 酸の缺乏は三要素を施用せずに石灰のみを施用して場合に，燐酸，加里を施用した場合に比し 少る.てれ石灰の施用にょつて土壤中の不可給態成分に變化されしものならん。

次江粐灰分量，灰分中の $\mathrm{SiO}_{2}, \mathrm{P}_{2} \mathrm{O}_{5}, \mathrm{CaO}$, 粐空素含有量及炭水化物合有量の消息老見 ると次の栐である。

第 20 表 粐組成分の相關關係

\begin{tabular}{l|l|l|l|l|l}
\hline 事 項 & 澏 名 & $\mathrm{N}$ & $\mathrm{P}$ & $\mathrm{K}$ & $\mathrm{Ca}$ \\
\hline 灰 分 量 & 1.00 & 0.71 & 0.63 & 0.66 \\
$\mathrm{SiO}_{2}$ & 1.00 & 0.92 & 0.95 & 0.78 \\
$\mathrm{CaO}$ & 0.70 & 0.88 & 0.89 & 1.00 \\
$\mathrm{P}_{2} \mathrm{O}_{5}$ & 0.68 & 0.87 & 1.00 & 0.64 \\
$\mathrm{~N}$ & 1.00 & 0.57 & 0.52 & 0.52 \\
glucose & 0.60 & 0.91 & 1.00 & 0.91 \\
平 & 0.83 & 0.81 & 0.83 & 0.77 \\
\hline
\end{tabular}

第 20 表に見るが如く各區の比較は $0.77 \sim 0.83$ 亿て石灰品用區最も惡く，次いで燐酸單用區， 䇪素單用區，加里單脯區の䐓である。

粐成分の燐酸含有量之炭水化物の含量に就いて考へて見るに，燐酸含有量は燐酸を多量に施

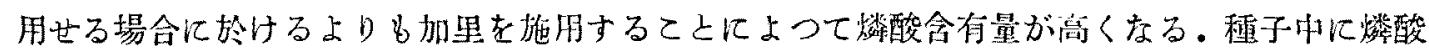
含有量の多いもの程發芽步合が高的と言はれてるるが若しもか上らな場合には燐酸を多く施朋

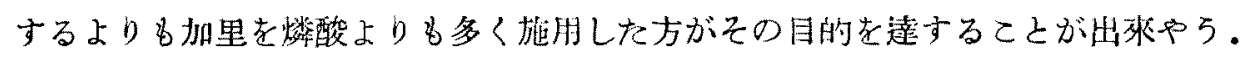

炭水化物の含有量を見るに加里の施用水上つて他の何れの區上り女多く，加里の效果は脂肪 及び炭水化物の形成に可成りの相關關係のあるものの如く考へらる。

份石灰の含有量を見ると石灰を多量几施したる場合に於いても加里を多量に施用した場合に 比し粐灰分中の石灰含有量の少ないのは如何なる關係にあるものか，更に之等の成分の临係孝 肥料要素各區に於ける場合上比較して見ると次の檬である。

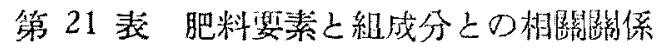

\begin{tabular}{|c|c|c|c|c|c|c|c|c|c|}
\hline 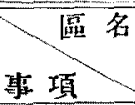 & N.P. K & P. K & N. K & N.P & Non, $M$ & $\cdot N$ & $\mathrm{P}$ & $\mathrm{K}$ & $\mathrm{Ca}$ \\
\hline 灰 分 & 0.73 & 0.88 & 0.78 & 0.72 & 0.91 & 1.00 & 0.71 & 0.63 & 0.66 \\
\hline $\mathrm{SiO}_{2}$ & 0.70 & 0.85 & 0.86 & 0.76 & 0.90 & 1.00 & 0.92 & 0.95 & 0.78 \\
\hline $\mathrm{CaO}$ & 0.90 & 0.72 & 0.68 & 1.00 & 0.45 & 0.59 & 0.75 & 0.76 & 0.85 \\
\hline
\end{tabular}




\begin{tabular}{l|l|l|l|l|l|l|l|l|l}
$\mathrm{P}_{2} \mathrm{O}_{\overline{5}}$ & 1.00 & 0.79 & 0.62 & 0.70 & 0.27 & 0.40 & 0.51 & 0.59 & 0.37 \\
$\mathrm{~N}$ & 0.48 & 0.42 & 050 & 0.62 & 0.38 & 1.00 & 0.57 & 0.52 & 0.52 \\
平 均 & 0.76 & 0.73 & 0.69 & 0.76 & 0.58 & 0.79 & 0.69 & 0.69 & 0.64 \\
\hline
\end{tabular}

第 22 表 $\mathrm{CaO}, \mathrm{P}_{2} \mathrm{O}_{5}, \mathrm{~N}$ の肥料要素との關係

\begin{tabular}{|c|c|c|c|c|c|c|c|c|c|}
\hline 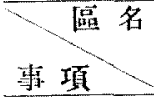 & N. P. K & P. K & N. K & N. P & Non. $M$ & $N$ & $P$ & $\mathrm{~K}$ & $\mathrm{Ca}$ \\
\hline $\mathrm{CaO}$ & 0.90 & 0.72 & 0.68 & 1.00 & 0.45 & 0.59 & 0.75 & 0.76 & 0.85 \\
\hline $\mathrm{P}_{2} \mathrm{O}_{5}$ & 1.00 & 0.79 & 0.62 & 0.70 & 0.27 & 0.40 & 0.51 & 0.59 & 0.37 \\
\hline $\mathrm{N}$ & 0.48 & 0.42 & 0.50 & 0.62 & 0.38 & 1.00 & 0.57 & 0.52 & 0.52 \\
\hline 平均 & 0.79 & 0.64 & 0.60 & 0.77 & 0.37 & 0.60 & 0.61 & 0.62 & 0.58 \\
\hline
\end{tabular}

第21表、第 22 表によれば石灰の吸收は加里の缺乏によつて石灰を多量に施用した場合よ りも多い，窒素の缺乏は左程でないが，窒素を多量に施用せる場合には石灰の含有量は減少を 來たせり。

燐酸の缺乏は燐酸のみを多量に施用したる場合よりる石灰の含有量を減少せしめる㥞で ある・

籾灰分中の燐酸含有量と肥料要素との關係は窒素の缺乏は窒素を多量に施用した場合に比し

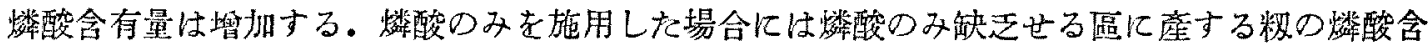
有量は少ないのであるが，燐酸の吸收は加里の多少によつて影響されるものの如く，加里の過

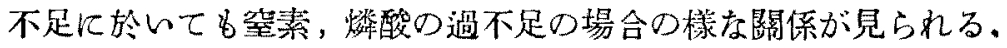

粐窒素合有量と肥料要素との關係は窒素の缺乏によつて減少し，多量に施肘することによつ て增扣するが，石灰及燐酸の場合に比し復㒕でない。

燐酸の缺乏は加里の缺乏よりも穻素の含有量を減少せしめ，之に反し燐酸のみを施朋しを場 合には沜里のみを施用した場合に比し少しく䇪素含有量を增加する。

窒素の吸收には加里の過不足上りも燐酸の過不足に上り影響されることが知られたり。

\section{第十一章 總括}

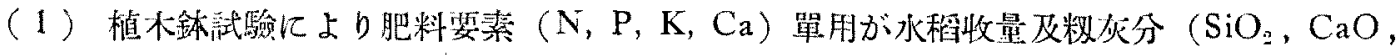

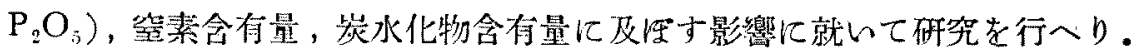

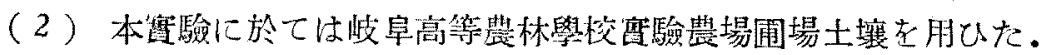

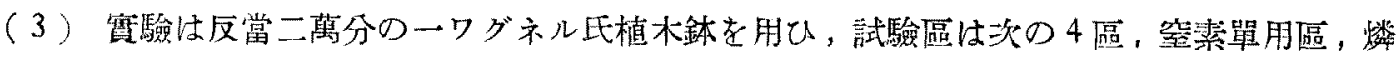
酸單用區，加里單用區，石灰單用區である。

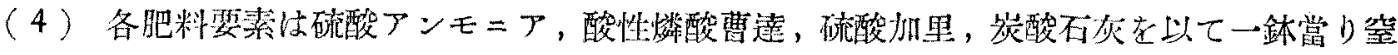

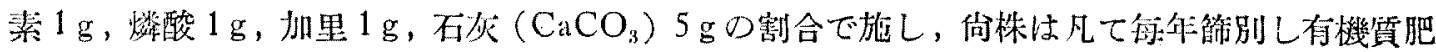
料は一切添加せす、。 
（5）本䔈驗は自昭和 6 年至同 9 年之を施行したが，生育及收量調查は昭和 6 年，7 年，8

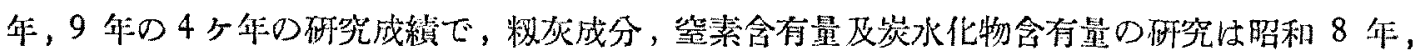
9 年の 2 ケ年の成績でする。

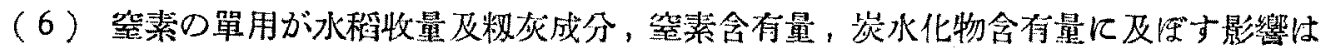

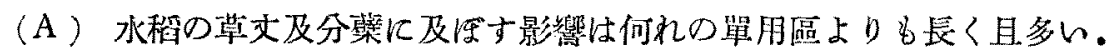

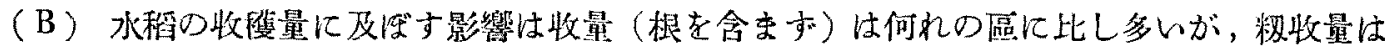
減少し石灰單用區に比し少ない。

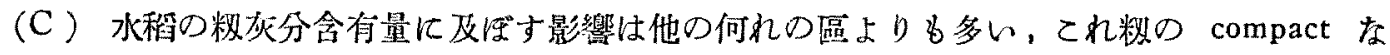
らざるため粐朢の多いのに原因する。

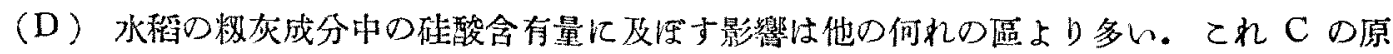
因に基く它戈入られる。

（E）水程の粐灰成分中の石灰含有量に及汪与影響は他の何れの區に比し少ない。

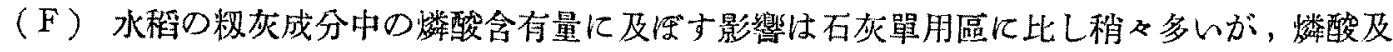
加里單用區に比し著しく減少せり。

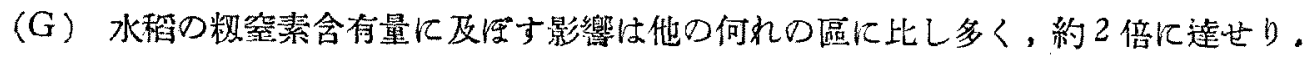

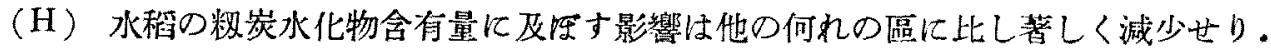

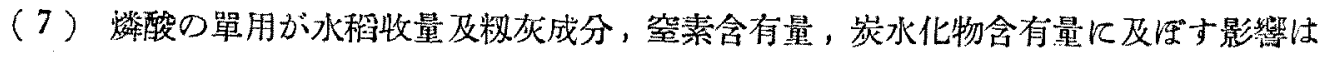

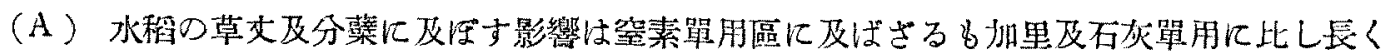

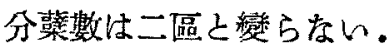

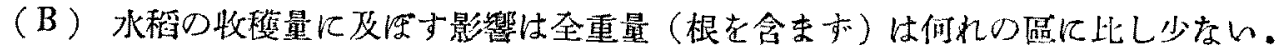

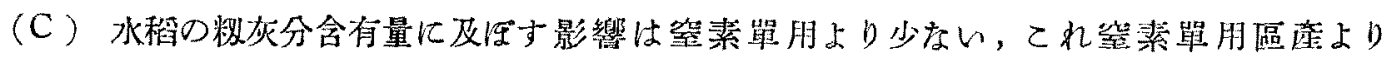
compact なるためであら5.加里及石灰單用區に比し多少多い。

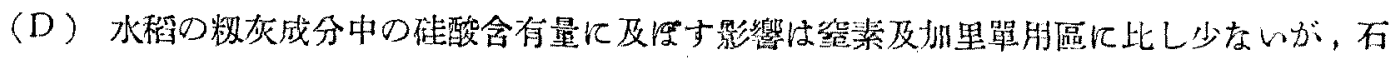
灰單朋區に多い，加里單朋區の灰分量の多いのに比し倠酸含推量を少しく減少世り。

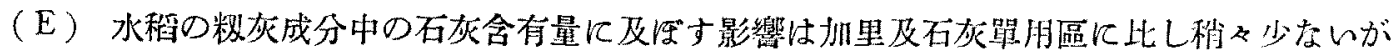
空素單用區に比し多々。

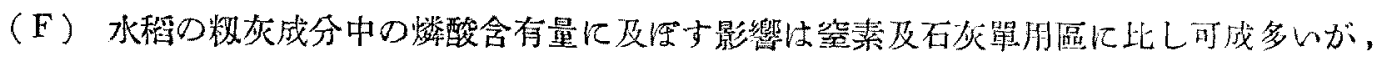
㸝里單用區に比し稍飞少ない。

（G）水稻の粐窒素含有量に及㥓す影響は窒素單用區に比し著しく少存いが，加里及石灰單 用區に比し少しく多い。

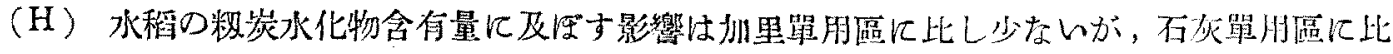
し少しく多く塋素單用區に比し著しく多い。

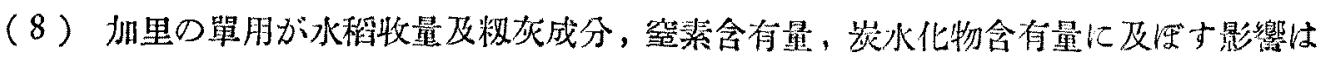




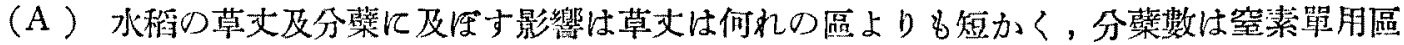
に比し少ないが燐酸及石灰單用區と殆ど琴がない。

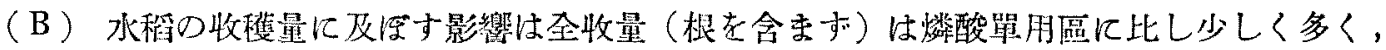

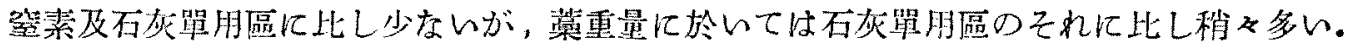

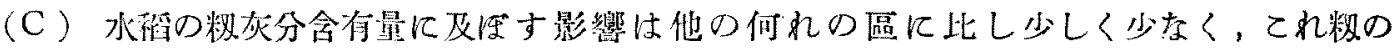
compact なるによる

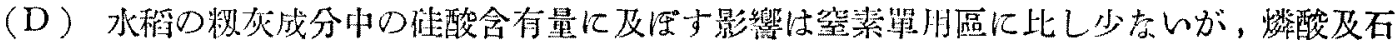
灰單䏳區に比し稍を多い。

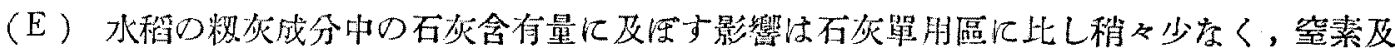
燐酸單朋區に比し少しく多い。

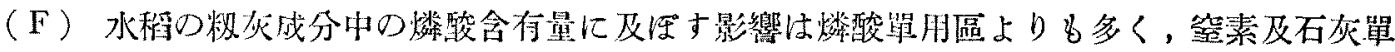
肪區に比し著しく多い。特に燐酸單朋區より\&多い點は面白い。

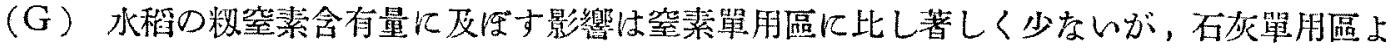
りも少しく多く燐酸單用區よりも少しく少ない。

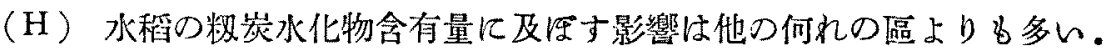

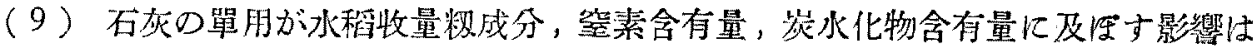

（A）水稻の草丈及分菜に及医す影響は空素及燐酸單䏳區に比し多少短汃く，扣里單用區に 此し少しく長い。

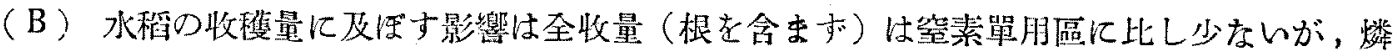
酸及加里單朋區よりも多い。籾重量に於いては何れの區よ方多多い。

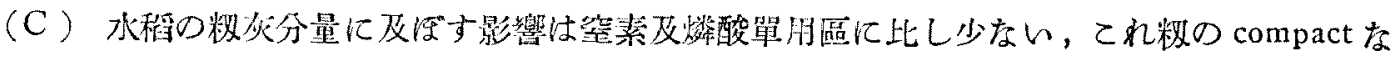
るためである。加里單佣區に比し少しく多い。

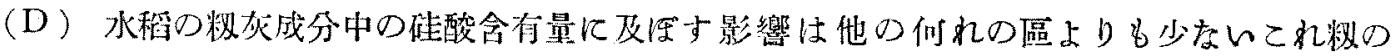
compact なるとよ゙考へられる。

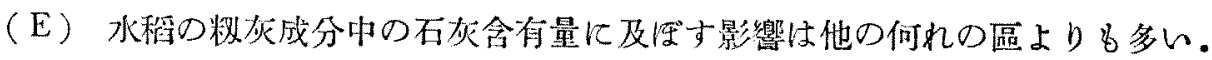

（F）水稻の粐灰成分中の燐酸含有量に及在寸影響は他の何狆の區上りる少なく，石灰の之 れよ反䶊の含有量老示してるる。

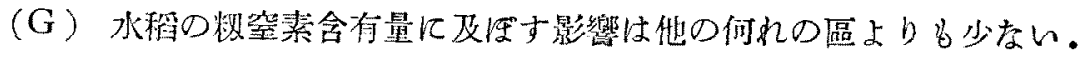

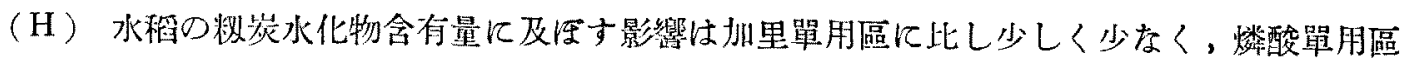
に比し大落がなく，空素單用區に比し著しく增加せり。

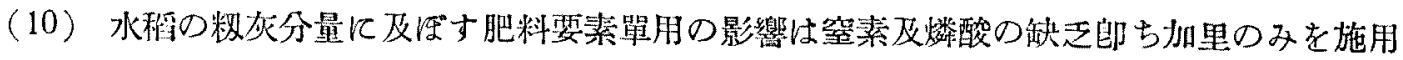

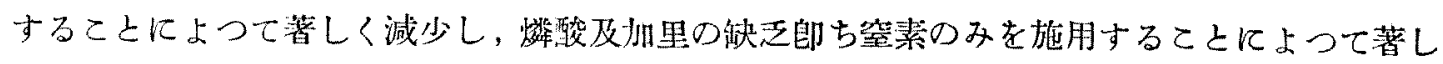

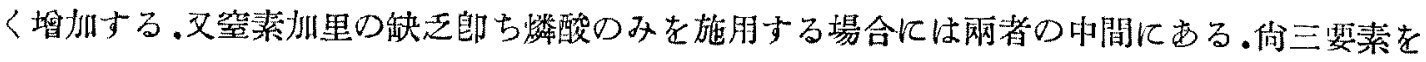


施用せ和石灰のみを施用することによつて灰分は著しく減少される。

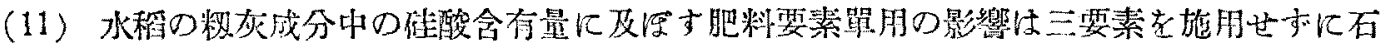
灰のみを施用することによつて著しく減少し，窒素及加里の缺乏郎ち燐酸のみを施朋する場合

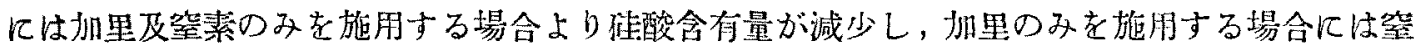
素のみを施用する場合に比し少ない。

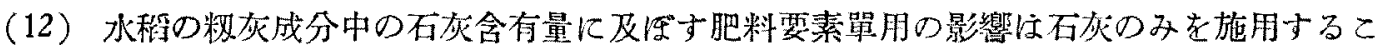

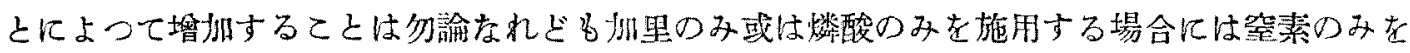
施用する場合に比し石灰量多く，加里のみを施用する場合には燐酸のみ克施用する場合に比し 少しく多い。

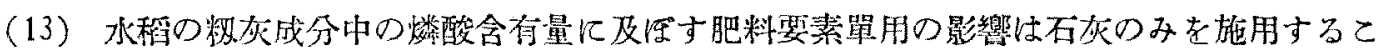
こによつて著しく減少される。燐酸及空素の缺之郎ち加里のみを施用することによつて燐酸の

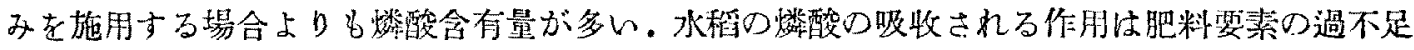
及び士堙の反應の如何に上つて影響されるるのの如し。

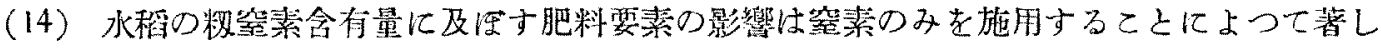
く戟加するが他の要素によつて餘り影響されない。

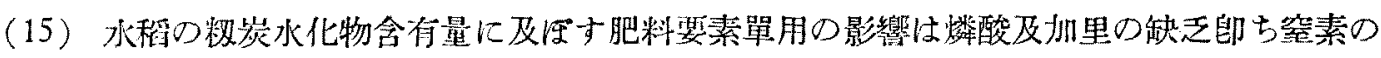
みを施用することによつて著しく減少し，燐酸或は石灰のみ老施用する場合に比し稍々少ない が网者の間に大差なく，加里のみを施用することによつて著しく炭水化物含有量が霄加するが 炭水化物の生成に加里の效果が著しいてとが知られる。

（16）水稻の籹窒素吸收に及痤す肥料要素の影響は燐酸及び加里を多く施用する場合よりも 少なく施用した場合には吸收が多くなり，扠里を多く施用する場合には燐酸を多く施用する場 合に比し多く，加里を少なく施用する場合には燐酸を少なく施用する場合に比し空素の吸收が 多くなるが如し.

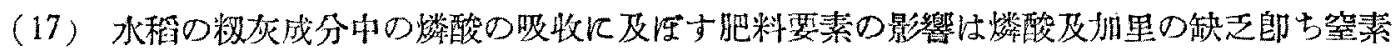
のみを施用することによつて著しく減少され，空素の缺之によつて燐酸或は肌里の缺乏による よりも燐酸の吸收が多い，燐酸のみを施用した區に於いては燐酸の缺乏區よりも少をく，加里 區に於いては加里のみを施用した區は加里の缺乏區よりも燐酸の吸收が少ない。

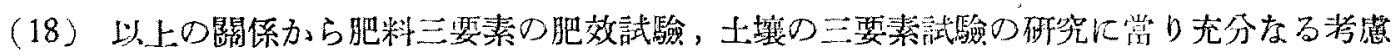
老必要とすると共にその間の消息を明かにした。

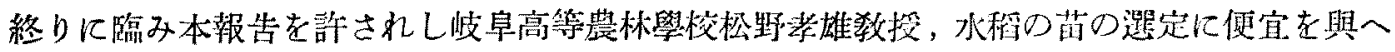
られたる岐阜縣農事試驗場園时技们，丹犲技手の御好意によりたるものにして本㟬驗に際し多 大の利便を得をり此處に記して深く謝意を表す。 


\section{第十二章 文 㱆}

（1）古川親交：日啙化，122，1115 (1934).

(2) 市川親交：日農化，127，255(1935).

(3) 市川親文: 日量化, 137, 114 (1936)

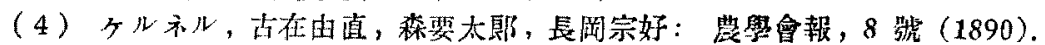

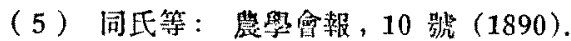

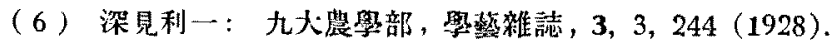

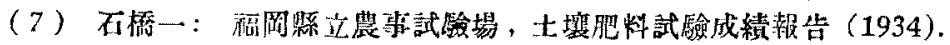

（8）高崎卷：土㵵肥料雜誌，3，4，44 (1929).

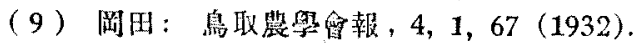

（10）场正太郎：莀繁會報，169，611 (1916)。

(11) W. A. Davis: Agr. Jour. India., 12, 77 (1917),

(12) 管日丰新一郎: 日農化, 111, 1331 (1933).

（13）春日井新一郎：日宸化, 112, 31 (1934).

（14）春日井新一郎：日農化，113，193（1934）.

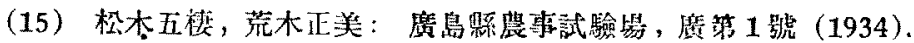

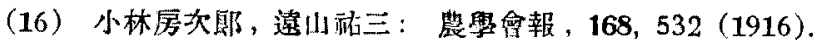

(17) A. Jocob: Zeits. für. Pflanz, Düng. u. Bodenk,, 37, 12, 1 (1935).

（18）野村盛久, 坂井信行: 土㭚肥料學誰誌，4，2，1（1930).

（19）水野大三：土堆肥料學雜融，2，2，55（1928）.

（20）深澤大三：土壤爬料學猚硙，5，3，1 (1931).

(21) J. W. Giusburg and J. W. Shive: Soil Sci., 22, 175 (1926).

(22) J. G. Lipman and A. W. Blair: Soil Sci., 4, 7l (1918).

(23) J. G. Lipman, A. W, Blair and A. L. Prince: Proceedings of the Tuter. Soc. of Soil Sci., 2, 3 (1926).

(24) F. W. Parker and E. Trung: Soil Sci., 10, 49 (1920).

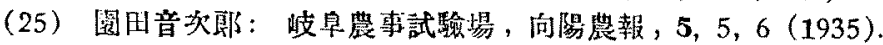

（26）里村辉男：旭硝子株式會社試驗所報告， 16, 73 (1926).

(27) K. Nehring: Zeits, fïr. Pflanz. Dung. u. Bodenk., 29, 320 (1933).

（28）石塚喜明：日農化，130,574（1935).

(29) A. W, Blair and A. C. Mc. Lean: Soil Sci, 1, 489 (1916).

(30) J. G. Lipman and A. W. Blair: Soil Sci., 7. 41 (1918).

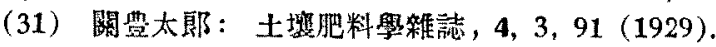

（32）书川親文：植物學雜誌，47, 558，471 (1933).

(33) T. Pfeiffer, E. Blanck, W, Simmer and W. Rathmann: Jour. Chem. Soc,, 108, 763 (1915).

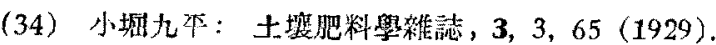

（35）偆日井新一郎：土壊肥料學雜誌，1，1，32(1927).

（36）春日井新一郎：土烄肥料學雜誌，3，1，31（1929．

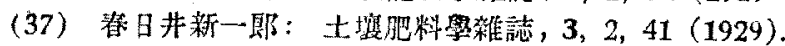

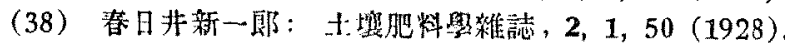

(39) 春日井新一郎：士塯肥料學雉誌， 4, 1, 75（1930).

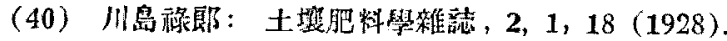

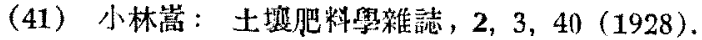

（42）小林嵩：土㜔肥料學雜誌，2，4，23 (1928).

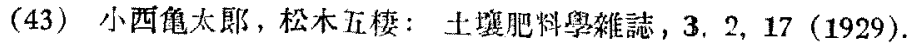

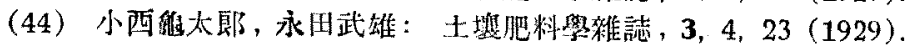

（45）手島周火即：土笠肥料學雜誌，4，3，73(1930).

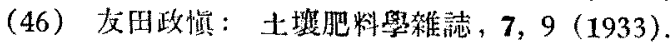

（47）藍素也：土嚓把料學雜誌，9，127（1935）。

(48) E. J. Kraus and H. R. Kraybill : Oregon. Agr. Exp. Sta. Bull, 149 (1918).

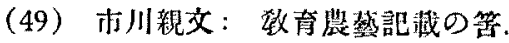

